\title{
Educational opportunities for adults with intellectual disability - Polish experiences
}

\author{
Kamila Gandecka, $\mathrm{PhD}$ \\ University of Wroclaw \\ e-mail: kamilagandecka@gmail.com
}

DOI:10.5901/mjss.2014.v5n19p418

\begin{abstract}
So far, the majority of both research and social policies regarding education of individuals with intellectual disabilities focused on children and adolescents, who were targets of numerous programs meant to adjust both learning materials and methods of teaching to their needs. At the same time, the issue of continuing education for adults with intellectual disabilities has been marginalised or even completely ignored. This was partially due to the fact that these people, no longer being subject to mandatory education, remained outside of the educational system and thus tended to be overlooked, which meant that there were few - if any - educational opportunities available to them. Another issue to consider was the very low level of awareness in the society regarding the need to activate this group of people both socially and occupationally. This situation has changed considerably during the last 25 years and still continues to change. There are far more opportunities for adults with learning disability to actively participate in specially designed activities. There is also a fundamental shift in the perspective on the role of such activities, from programs meant to fill the disabled person's time to more structured educational programs aimed at promoting independent functioning and integration with the society, as well as acquisition of skills which would allow them to undertake meaningful work within supported work environment. These programs also aim to act against prejudice and discrimination and to shift the view of an intellectually disabled person from an "eternal child" to an adult with concrete skills and abilities. The aim of the current research is to explore these social, legislative and educational changes in Poland during the last 25 years, using the example of Lower Silesia region. The study employed the methods of pedagogical monograph, which analysed functioning of three occupational therapy workshop facilities in the region, unstructured interviews with professionals working with adults with intellectual disabilities, as well as document analysis, which included legal documents regarding the issue. It was concluded that although the educational opportunities of adults with intellectual disabilities have improved over the last two decades, mostly due to activities of many local non-governmental organizations and their innovative programs, there are still many physical, societal and psychological barriers in access to continuing education for adults with intellectual disabilities. It was found that currently in Lower Silesia the only form of meaningful and practically useful further education available are the occupational therapy workshops.
\end{abstract}

Keywords: education, intellectual disability, adults, Poland

\section{Introduction}

The unceasing interest within various scientific fields, especially in the last two decades, in the issue of disability and the quality of life of individuals with different dysfunctions, has certainly brought concrete results. Theoretical examination and conducted empirical research, especially in the fields of social and biomedical sciences, have contributed to the emergence of a new perspective on the needs, role and a place in society of disabled individuals, as well as the problems they must face every day. This view justified the abandonment of the one-sided, medical model of disability, based on the individual's state of health and limitations resulting from it, and the movement towards holistic perception of disabled individuals. A comprehensive approach to the phenomenon of disability is associated with the issues of human dignity and human rights, as well as the social model of disability, which emphasises the individual's abilities, not limitations stemming from a concrete dysfunction or a cluster of dysfunctions.

The developed concepts and practical strategies are part of the process of normalisation, which includes many areas of social life, in particular education, occupational and social rehabilitation, cultural and sport activities, etc. What is more, numerous legislative initiatives also facilitate actions aimed at preventing discrimination and marginalisation of disabled people, especially those with intellectual disability.

Persistence of the aforementioned tendency stems from several factors. One of the most important ones is the prevalence and scope of the phenomenon of disability, which is being "(...) exposed in circumstances of general revealing of problems which used to be hidden or treated as marginal in scope" (Golinowski, 2004, p.15). 
Individuals with various dysfunctions have always been, are and will be present in the social, political and cultural space, regardless of the dynamics of changes occurring in the developing world. As Malec (2008, p.47) writes: "Disability is not a matter of choice, we have no influence over it - each of us could have been born as a disabled person and each of us may become disabled at some point in our lives. (...) When we are healthy physically, psychologically, sensorily - fully abled we do not give any thought to our disabilities. We go on living, convinced that we possess such an 'apparent' full ability, until an event occurs (an accident, a paralysis or illness, etc.) which forces us to redefine ourselves, to construct a new image of ourselves in the new circumstances".

Another important impulse emerging in today's world are the postulates of tolerance and equal opportunities for various minority groups, especially the disabled. This impulse is reflected in regulations, obligations and strategies of the European Union and other international organisations working for the benefit of disabled people (see: Obuchowska, 2008). What is more, the presence of the disabled in the society becomes more and more visible, and is increasingly emphasised by the disabled persons themselves, as is the founding of various organisations and associations of parents, leaders and activists representing and acting in the interest of this social group.

Summarising, life situation of disabled people depends on many factors. Alongside health, level of functioning and psychological factors an important role is played also by social status and family situation of the disabled person, as well as the economic situation of the country, current legislation and the model of social policy. Undoubtedly, these factors constitute a manifestation of social attitudes towards disabled individuals, which are very diverse (Osowska, 1997).

My interest in the issue of the direction of changes occurring in the field of educational opportunities for adults with intellectual disability in Poland stems from personal experience. In the years 2007-2009 I took part in implementation of the scientific and educational project "Assistant of Karkonosze College staff member. A person with an intellectual disability on the road to employment in the open market" 1 , run at the Panstwowa Wyzsza Szkola Zawodowa w Jeleniej Gorze [State Higher Vocational School in Jelenia Gora]2. It is worthy of note here that the proposed form of vocational internships for adults with intellectual disabilities was acknowledged as pioneering work in Poland.

Beneficiaries of the aforementioned initiative were nine adults with intellectual disability, four men and five women, who regularly participated in occupational therapy workshops in Jelenia Gora. For one day a week they would become assistants to some of the College's staff, including:

to lecturers from Pedagogy Institute and Institute of Medical Education, where they assisted during various classes, including, among others, general pedagogy, special needs pedagogy, sign language, first aid and art therapy (duties included: operating multimedia equipment, distributing learning materials, tidying up, taking printing orders etc.) -5 persons;

to technical staff (duties included: cleaning and repairs on the College grounds) - 1 person;

secretarial office of the Pedagogy Institute (duties included: simple office work) - 1 person;

printing service staff (duties included: taking orders, copying, binding etc.) - 2 persons (Fornalik, 2008).

The main goal of the "Assistant" project was the inclusion of individuals with intellectual disabilities into the college community as part of their vocational internship, thus providing them with an opportunity to enter a wider social environment, beyond special needs institutions, as well as to be in contact with their peers - the students. What is more, the chance to be active and needed was also a unique opportunity to gain general experience of being an employee (Fornalik, 2008). Without doubt this project brought many benefits, and not only for its primary recipients. Both the college staff and the students were given a real opportunity to experience social integration, as well as to confront their ideas about people with intellectual disability, their needs or life circumstances with reality. One of the concrete results of the described project is the fact that, despite the project having ended, the College still invites the help of the assistants. In this case the presence of adults with intellectual disability has become a permanent element of the College's everyday life.

Another important element to consider when talking about the issue of disability is the definitional chaos surrounding the concept. During the last few decades the approach to the notion of disability, including intellectual disability, has changed in a revolutionary way. Currently analyses of the phenomenon of disability most often utilise the constructivist model, which

\footnotetext{
${ }^{1}$ First, pilot edition of the initative took place in the academic year of 2006-2007, and was financed entirely from the funds provided by the City Council of Jelenia Gora. Authors of the "Assistant" program are Izabela Fornalik and Mirella Michalewska-Pajak, at that time lecturers and researchers at the College.

${ }^{2}$ Since 2012 the school runs under a new name. Currently it is known as Karkonosze College in Jelenia Gora.
} 
sees disability as a result of the relationship between an individual and his environment, especially in its social aspect (Szumski, 2006).

Assuming that human being and her dignity constitute worth, the phrase "disabled person" is a form of a more detailed elaboration, which fits within the trend of personalism. What is more, such formulation of the term shows the primary importance of the person, not her disability.

Thus, when discussing the issues regarding normalisation of life of individuals with intellectual disabilities we no longer concentrate on obstacles and limitations within the disabled person, but rather on the obstacles stemming from his social and physical environment. Eliminating the obstacles and limitations within the environment is a basis of prevention of the phenomenon of discrimination and social exclusion, a premise which is reflected in various international and national documents.

Multidimensionality and universality of the phenomenon of disability makes it very difficult to develop a single, coherent and generally accepted definition. The social dialogue concerning this issue should be continued, not only within the scientific field. At the same time it is important to maintain the terminological transparency of subsequently developed new interpretations of the phenomenon of disability.

A brochure published in 2010, titled "The Ten Commandments for talking about intellectual disability" is a good example, illustrating the necessity of undertaking social initiatives aimed at creating an appropriate image of a person with such dysfunction. The publication was created as an initiative of non-governmental organisations acting for the benefit of people with intellectual disability and is aimed mostly at the representatives of the media, which exert strong influence on social attitudes. The aims of the authors include, among other things:

creating easily accessible materials, which will make it easier to present individuals with intellectual disability in the media in the way beneficial to their integration;

organising the language used both in the media and in everyday life with regard to intellectual disability; promoting - especially in the case of journalists - the appropriate language and way of speaking about intellectual disability; raising awareness of journalists regarding intellectual disability;

helping to raise the level of acceptance and understanding of individuals with intellectual disability in society in general.

Additionally, the brochure included basic information about what intellectual disability is and how it differs from mental illness.

To summarise, educational opportunities for adults with intellectual disability depend on numerous and complex factors, including social attitudes towards disability, as well as current legislation and social policy regarding this issue. The aim of this study was to explore the process and conditions of these social and legislative changes, which determine the development of education for persons with intellectual disability in Poland, as well as to present the forms of education currently available to adults with intellectual disability.

\section{Method}

The starting point for the examination of educational opportunities of adults with intellectual disability were the results of research conducted as a part of my doctoral thesis, submitted for public defence in April 2011 in the University of Wroclaw Pedagogy Institute. The subject of this research exploration was an analysis of the conditions influencing the process of creation of theoretical bases and the organisation of special needs education, as well as other forms of education available to individuals with intellectual disability in Poland after 1989, using the Lower Silesia region as an example 1. The current study aimed to deepen the understanding gained from previous research. It was conducted using the interpretative paradigm, which seems to be the most appropriate for exploration, analysis and understanding of the process of creating educational opportunities for adults with intellectual disabilities, since this process is determined by its given time period, social reality and cultural context within which it takes place. What is more, the aforementioned research perspective assumes a combination of methods, selection of most significant aspects of the studied phenomenon as well as the researcher's involvement in the attempt to understand as well as possible, to analyse and to interpret the chosen aspect in the context of her accumulated knowledge and experience (Malewski, 1998).

\footnotetext{
1 The research was supervised by Professor Stefania Walasek.
} 
The main research methods in this study were the pedagogical monograph and the unstructured interview. A source of valuable reflections and comments regarding the changes in the social situation of individuals with intellectual disability, as well as actions undertaken as part of their occupational and social rehabilitation, including trends in education, were the interviews with, among others, Ms. Ewa Kasinska - the Head of the Health and Social Policy Department of the City Council of Jelenia Gora (up to 2012), Danuta Zmijowska - manager of the Occupational Therapy Workshop of the Polish Society for Individuals with Intellectual Disability (Polskie Stowarzyszenie na Rzecz Osob z Uposledzeniem Umyslowym, PSOUU), Ms. Lucyna Szpak - vice-president of the Jelenia Gora Section of the Association Against Disability (Jeleniogorski Oddzial Towarzystwa Walki z Kalectwem) and with Ms. Dorota Blachowska - manager of the Occupational Therapy Workshops of CARITAS in Legnica Diocese 1.

A perfect complementation of the aforementioned methods was document analysis. The selection of source material closely followed the topic outlined in the title of this article. A special place in the source database was granted to interview questionnaires, which aimed to explore opinions regarding the fulfilment of educational needs of adults with intellectual disabilities. Another important source of information were legislative acts in the form of laws, ordinances and directives, as well as documents describing European and international standards, which Poland has accepted or taken a stand towards.

So far, research regarding organisation and course of education of people with intellectual disability focused its analysis much more often on the educational situation of children and adolescents, whereas the needs and problems of adults with intellectual disability with regard to widely understood education have been marginalised or even completely ignored. This was due to the fact that those people, no longer being subject to mandatory education, remained outside of the educational system. What is more, after completing their education at the elementary level these individuals would often "disappear" within the area of the out-of-school education. This was because there were no alternative routes of education for this group of people. What is more, the need to activate this group of people, both in the social and, even more importantly, occupational areas, was disregarded.

The turning of attention towards the dignity of the disabled persons in the process of social integration, especially in the educational field, is a result of deep changes, which have occurred in the awareness of our society within the last 25 years. It is associated with changes in the value system and ways of acting in many aspects of life, as well as with getting rid of prejudice and viewing each person as a partner. Reform initiatives aimed to secure access to education for everyone, undertaken by various groups, move Poland closer to the standards in force in other countries of the European Union (Przybysz, 2005). These changes in legislation were a subject of detailed analysis in this study.

With regard to the researcher's perspective and values, in the present study I took the dignity of a human person as a primary value. According to philosophical anthropology of Karol Wojtyla (Wronska, 1999), a person is a "somebody". This phrase indicates the person's fundamental worth, which in the personalistic perspective is the dignity. The person draws her dignity from inner perfection - spiritual perfection, which only she possesses out of all creation. That which the human is in and of himself is associated primarily with his inside. Each outward expression of the person, manifested, among other things, in his actions or creativity, stems from his spiritual nature, that is, the natural basis of the dignity of the person. The worth of a human person is "(...) particular and fundamental, which makes it independent from this or another physical or psychological quality, from her external or internal possessions." (Wronska, 1999, pp.187-194). The human person in this sense should be viewed as a single and indivisible subject of possible initiatives and involvements.

\section{Results}

\section{Findings of Demographic Variables}

The background for examination of educational opportunities of the studied group is the description of social and economic situation of disabled persons on a nation-wide level, with particular attention paid to Lower Silesia.

The number of disabled persons in Lower Silesia equals 383,000, which constitutes $13.2 \%$ of the province's general population (on the country-wide scale this percentage is $12.2 \%$ ). When families, relatives and caregivers are taken into account, it turns out that more than half of Lower Silesians are somehow affected by the issue of disability (Social Research Laboratory, LLC \& MANDS Market and Opinion Research, 2013).

Analysis of the gathered data shows that disabled persons achieve lower levels of education than fully abled individuals. The reasons for this situation are varied and complex and include architectural barriers in schools colleges and universities,

1 I would like to thank my interviewees for their assistance, providing access to all important materials and for their insights. 
barriers in communication with the rest of the environment, problems associated with commuting to the place of education, lack of rehabilitation equipment and educational materials, as well as psychological barriers. Many schools in Lower Silesia still did not remove the architectural barriers. There is also the still unsettled question of what type of educational facilities are best suited for education of disabled persons - integrative or specialist ones. Although some types of disabilities require the education to take place in specialist facilities, it is still important to provide those disabled individuals who are able and willing with the opportunity to participate in integrative education.

The decidedly lower level of education of disabled people also translates into their lowered labour market participation, which in turn contributes to the high level of unemployment in this group of people. In Lower Silesia as many as $84.1 \%$ of legally disabled individuals are economically inactive. In comparison, among the fully abled people this percentage equals 44.5\%. In the group of disabled Lower Silesians who are economically active, the majority is employed in Supported Employment Enterprises - according to an analysis by Biuro ds. Polityki Spolecznej i Osob Niepelnosprawnych [Social Policy and Disabled Persons Bureau] this percentage equals around $70 \%$. Thus, the situation of the disabled people on the labour market in Lower Silesia province is among the worst in the whole country - with regard to both the percentage of economically active people and the employment rates, Lower Silesia occupies the last but one position among other provinces (respectively 12.3\% and 9.7\%; The Lower Silesia Strategy for Social Integration Project for the years 2014-2020, 2014).

The low level of economic activity is associated with serious financial troubles the disabled often struggle with. Data from

The Lower Silesia Strategy for Social Integration Project for the years 2014-2020 (http://www.dops.wroc.pl/aktualnosci2013/dsis1420.pdf) indicate, for example, that one in four families with a disabled member live in danger of poverty, $45 \%$ of disabled individuals do not buy the prescribed medicines due to poverty, and $95 \%$ of families have no access to the internet.

An important role in the process of social integration of disabled persons in Lower Silesia, as well as in the rest of Poland, is played by non-governmental organisations. There are 275 such organisations within the studied area, including some which operate nationwide as well as small organisations founded as an initiative of the local communities. Main activities of these organisations include:

identifying and publicising social problems,

forming coalitions to help solve problems,

developing and implementing concrete programs of assistance for the disabled persons,

conducting interventions (advocacy; Lower Silesia Strategy for Social Integration for the years 2005-2013, 2014).

In order to more fully implement the assumptions stemming from the postulate of social and occupational rehabilitation of the disabled the local authorities are constructing a network of cooperation with non-profit organisations. This cooperation aims to achieve, among other things, the following goals: formation of appropriate social attitudes, conducive to realisation of the rights of the disabled persons, increasing built environment accessibility for the disabled persons and increasing the level of independence and self-sufficiency of the disabled persons as well as of their level of education, and thus of their labour market participation. Another important issue in this regard is activation and support of activities of organisations founded by the disabled themselves and aimed at creating social policy.

\section{Findings of available educational opportunities for adults with intellectual disability}

An important task of education of adults with intellectual disability is the constant support of their development, help in understanding themselves as well as other people, with whom they will have relationships, and who have similar life problems, needs and experiences to all other people. The acquisition by the person with intellectual disability of particular abilities allowing her to participate in more and more complex systems of undertaken activities is a basis for formation of her individual and social identity, which takes form of a very dynamic and lifelong process. This is why continuing education of adults with intellectual disabilities is a fundamental necessity, facilitating their activation (Zolkowska, 2002). Thus understood education of adults with intellectual disability takes place especially during occupational therapy workshops.

As of 31th December 2008 there were 41 active occupational therapy workshops in Lower Silesia. With regard to the dynamics of development of such facilities in the studied area, the highest growth index was noted in 2005 and equalled $37 \%$ (the highest growth in the country). The average number of occupational therapy workshops per district in Lower Silesia province is 1.41 (INDICATOR Marketing Research Center, 2009). 
Undoubtedly the increase in number of such facilities is associated with civilisational and urbanistic aspects, but nonetheless the most important factor here is the awakened civic engagement. This is evidenced by the fact that the majority of occupational therapy workshops are organised and run by non-governmental organizations founded by parents of the individuals with intellectual disability, as well as other organisations working towards social integration, as well as by religious communities.

The functioning of the occupational therapy workshops will be presented using three facilities operating in Jelenia Gora and Legnica as examples: Warsztat Terapii Zajeciowej przy Polskim Towarzystwie Walki z Kalectwem Oddzial Terenowy w Jeleniej Gorze [Occupational Therapy Workshop of the Jelenia Gora Section of the Polish Association Against Disability] (operating since 1995), Warsztaty Terapii Zajeciowej Polskiego Stowarzyszenia na Rzecz Osob z Uposledzeniem Umyslowym Kolo w Jeleniej Gorze [Occupational Therapy Workshops of the Polish Society for Persons with Intellectual Disability "The Circle" in Jelenia Gora] (operating since 1998) and Warsztaty Terapii Zajeciowej CARITAS DIECEZJI LEGNICKIEJ w Legnicy [Occupational Therapy Workshops of CARITAS of the Legnica Diocese in Legnica] (operating since 2005). The selection criteria were the year of founding of the facility, founding and managing authority and achievements in the field of social integration. What is more, it turned out that an important factor for selection was the actual willingness of the facility to participate in the study and in possible further cooperation.

Occupational therapy workshops operate on the basis of regulations of the Occupational and social rehabilitation and employment of the disabled act, as well as the appropriate regulations regarding occupational therapy published by the Ministry of Economy, Labour and Social Policy. Article 7 point 1 of the aforementioned act reads: "Rehabilitation of disabled persons denotes an array of actions, especially organisational, medical, psychological, technical, training, educational and social ones, aimed to achieve, with the active participation of these persons, the highest possible level of their functioning, quality of life and social integration" (Journal of Laws [Dz. U.], no. 123, from 27th August 1997, item 776, as amended.). This understanding of the notion of rehabilitation indicates the importance of examination of the occupational therapy workshops program as an example of implementation of the concept of lifelong learning. Moreover, the legal definition of rehabilitation corresponds to the following definitions of education:

"(...) leading another person towards higher developmental states and his own activity aimed at achieving his full and unique ability" (Kwiecinski \& Sliwerski, 2003, p. 38),

"(...) The sum of experiences, which are significant with regard to formation of competence and identity of a person, or a sum of his interactions with the world of life, important for the optimal development of personality" (Dykcik, 2001, p. 63).

An occupational therapy workshop is a facility which gives those people with intellectual disability who are unable to work a chance to be rehabilitated socially and occupationally through the acquisition or restoration of skills necessary for employment. Additionally, participants of the workshops acquire skills needed for more independent life during various classes.

A participant who was qualified for therapy, is first "familiarised" with the facility, staff and other disabled persons and learns about types of activities available in a given workshop, as well as about the rules principles of its functioning and of rehabilitation. She gets to know each particular workshop for about one month, after which she chooses the workshop she would like to participate in for the next six months, or decides to attend several workshops (spending one month in each the so called rotational system). Parents or caregivers attend an initial interview at the stage of applying for a place in the workshop, and then at acceptance attend a formal interview. Learning as much as possible about the person's psychophysical state from the family is necessary for planning an effective rehabilitation program. The needed data are gathered on the basis of medical, psychological and pedagogical diagnoses. The participant is examined in the facility by a neurologist, with assistance of a rehabilitation therapist. Next, an individual plan of rehabilitation and therapy is developed within three months and presented to the parents, since effective rehabilitation always requires an active participation of the family environment.

Rehabilitation of individuals with intellectual disabilities proceeds on two levels simultaneously, and consists of both functional rehabilitation and initial occupational activation. The first area encompasses training of the following abilities: communication competency, personal care, independent social functioning, economic skills, and planning and decision making skills. On the other hand vocational education of the workshops' participants emphasises learning about the formal aspects of employment, such as applications, curriculum vitae, attendance, contracts, etc. Additionally, it aims to develop and increase awareness of the traits of a good employee in the participants. Emphasis is also put on developing team working skills and the ability to cooperate with a superior. This is achieved through organising classes within actual workplaces. 
Summarising, occupational therapy workshops constitute the only form of fulfilling the needs of adults with intellectual disability in an interesting and useful way available to them. Thanks to diverse classes these people become more selfsufficient, independent and responsible, which undoubtedly influences their subsequent employment in supported jobs.

\section{Discussion}

Social contacts between the disabled and fully abled people may take different forms, which are described as "visibility of the disabled in the society". In this context the process of integration gains features characteristic for both a social and a psychological phenomenon, which means that the barriers which are most difficult to overcome by both sides are the psychological ones. Thus, the following questions still seem to remain relevant: how to educate for integration? How to prepare people for the contact with a person with intellectual disability, so that they would not be apprehensive about her and her needs and would reach out to her? On the other hand, how to promote pro-social attitudes towards people with intellectual disability, how to develop empathy towards them? Meeting these challenges is one of the pressing issues of today's world.

It is assumed that the degree to which the problem of fulfilling educational needs of people with various disabilities is solved may serve as a basis for evaluation of the educational system as a whole. The basis for implementing changes aimed at creating society which is open to and accepting of individuals with lower intellectual or physical abilities, is the creation of non-segregating laws, especially with regard to access to education.

The educational system reform brought beneficial changes with regard to education of pupils with intellectual disability. Decentralisation of responsibility for education of pupils with special educational needs, which began in the early nineties, made it possible for local authorities to encourage and support schools in such a way which allowed the schools to make decisions regarding the best use of their own resources in order to fulfil the needs of all local pupils.

What is more, positive legislative climate, illustrated especially by the introduction of non-segregating regulations in educational laws, as well as the growing social awareness of the need to change conditions and the environment in such a way as to make it possible for disabled pupils to be schooled together with their healthy peers, have brought about changes in the structure of education of disabled pupils in Poland, visible since the mid-nineties, when the number of schools and pre-schools with integrative classes started growing dynamically.

The necessary condition for empowerment and adaptation of the person with intellectual disability in today's troubled, chaotic or even hostile world is a gradual, rational inclusion of this person into the social life of the environment he happens to live in. This can be done through assigning him tasks he is able complete, as well as through his learning about cultural objects of the given region, city, town, village, district, street, or family or neighbourhood community. Such actions aim to bring the person with intellectual disability closer to that which is common, which integrates people, which does not introduce artificial divisions between people who know and respect each other, which is valuable to everyone, which allows people to be happy, to experience, to love and be loved. Consequently, all this allows people to feel adult and whole. These assumptions are realised in the process of social and occupational rehabilitation of people with intellectual disability. Activity of the occupational therapy workshops is a good example of the implementation of the described concept, especially in the area of widely understood education, which gives individuals with intellectual disability an opportunity to experience their own identity and social integration.

Accompanying an adult with intellectual disability in their lifelong education consists mainly in teaching her to keep discovering her worth ever anew, despite her disability. It is nothing else but helping her in meeting ever new challenges which life brings.

\section{References}

Centrum Badan Marketingowych INDICATOR dla Panstwowego Funduszu Rehabilitacji Osob Niepelnosprawnych [INDICATOR Marketing Research Center, on behalf of the National Fund for the Rehabilitation of the Disabled], (2009). Analiza dzialalnosci warsztatow terapii zajeciowej w 2008 roku [Analysis of the activities of occupational therapy workshops in 2008], Warszawa. Retrieved from: http://www.pfron.org.pl/ftp/dokumenty/Badania_i_analizy/Raport_z_badania__Analiza_dzialalnosci_wtz_w_2008_roku.pdf (24/06/2014)

Dolnoslaska Strategia Integracji Spolecznej na lata 2005-2013 (Lower Silesia Strategy for Social Integration for the years 2005-2013; data file]. Retrieved from: http://www.dops.wroc.pl/strategia.php (24/06/2014).

Dykcik, W. (Ed.). (2001). Pedagogika specjalna [Special Needs Pedagogy], Poznan. 
Fornalik, I. (2008). Osoba z niepelnosprawnoscia intelektualna w szkole wyzszej? Projekt „Asystent” forma aktywizacji zawodowej osob niepelnosprawnych intelektualnie [A person with intellectual disability in college? The "Assistant" project as a form of vocational activation of persons with intellectual disabilities]. In A. Bartnikowska, Cz. Kosakowski, A. Krause (Eds.), Dyskursy pedagogiki specjalnej No. 7: Wspolczesne problemy pedagogiki specjalnej [Special Needs Pedagogy Discourses, Volume 7: Contemporary issues in special needs pedagogy]. Olsztyn.

Golinowski, S. (2004). Integracja spoleczna osob niepelnosprawnych. Ocena dzialan instytucji [Social integration of disabled individuals. An evaluation of the organisations' activity], vol. 25. Warszawa: Raport Instytutu Pracy i Spraw Socjalnych (IPiSS).

Kwiecinski, Z. \& Sliwerski, B. (Eds.). (2003). Pedagogika. Podrecznik akademicki, tom 1 [Pedagogy. A textbook. Vol. 1], Warszawa.

Laboratorium Badan Spolecznych Sp. z 0.0. [Social Research Laboratory, LLC) and MANDS Badania Rynku i Opinii [MANDS Market and Opinion Research], 2013. Badanie sytuacji osob niepelnosprawnych na dolnoslaskim rynku pracy i edukacji - raport koncowy $z$ badan [Investigation of the situation of disabled people in the labour and educational markets in Lower Silesia - a research report]. Wroclaw.

Malec, M. (2008). Spoleczne praktykowanie/konstruowanie (nie)pelnosprawnosci, [Social practice/construction of (dis)ability], Nasze Forum, 1-2, 47.

Malewski, M. (1998). Teorie andragogiczne. Metodologia teoretycznosci dyscypliny naukowej [Andragogy Theories. Methodology of the Theory of Scientific Discipline], Wroclaw.

Obuchowska, H. (2008). Kierunki dzialan w polityce Unii Europejskiej wobec osob niepelnosprawnych [Directions of actions in the European Union policy regarding disabled persons]. Krakow.

Occupational and social rehabilitation and employment of the disabled act of 27th August 1997 (Journal of Laws [Dz. U.], no. 123, from 27th August 1997, item 776, as amended.)

Osowska, A. (1997). Postawy spoleczenstwa polskiego w stosunku do osob niepelnosprawnych, [Attitudes of the Polish society towards disabled persons]. In A.Gustavsson, E. Zakrzewska-Manterys (Eds.), Uposledzenie w spolecznym zwierciadle [Disability in the social mirror]. Warszawa.

Projekt Dolnoslaska Strategia Integracji Spolecznej na lata 2014-2020 [The Lower Silesia Strategy for Social Integration Project for the years 2014-2020; data file]. Retrieved from: http://www.dops.wroc.pl/aktualnosci2013/dsis1420.pdf (24/06/2014).

Przybysz, A. (2005). Niepelnosprawni w europejskim systemie edukacji [The disabled in the European education system], Edukacja i Dialog, 1

Szumski, G. (2006). Integracyjne ksztalcenie niepelnosprawnych. Sens i granice zmiany edukacyjnej [Integrative education of the disabled. The meaning and boundaries of educational change]. Warszawa.

Wronska, K. (1999). Karola Wojtyly personalistyczna filozofia wychowania, [Karol Wojtyla's personalistic philosophy of education]. In F. Adamski (Ed.), Wychowanie na rozdrozu. Personalistyczna filozofia wychowania [Education on the crossroads. Personalistic philosophy of education]. Krakow.

Zolkowska, T. (2002). Poczucie wsparcia spolecznego doroslych osob niepelnosprawnoscia intelektualna a poziom ich aktywnosci., [The sense of being socially supported in adults with intellectual disability and the level of their activity]. In W. Dykcik, Cz. Kosakowski, J. Kuczynska-Kwapisz (Eds.), Pedagogika specjalna. Szanse na realizacje potrzeb osob z odchyleniami od normy [Special Needs Pedagogy. Opportunities for fulfilling the needs of persons with dysfunctions], Olsztyn-Poznan-Warszawa. 